\title{
"Post-etnisitas" Kazuo Ishiguro
}

oleh Ferina Meliasanti*

Selesai membaca tulisan Anwar Holid tentang Martin Amis "Badabudu dan Martin Amis", Khazanah, Pikiran Rakyat, (3/5), saya teringat pada karya-karya Kazuo Ishiguro. Seingat saya, Martin Amis dan Kazuo Ishiguro merupakan regenerasi penulis dalam kancah sastra Inggris pada awal era 1980-an, yang telah menjadi bagian penting dalam percaturan sastra dunia hingga saat ini. Namun, saya tidak hendak membandingkan keduanya. Meski keduanya memiliki strategi dan karakteristik karya yang berbeda, namun kekuatan karya mereka sama-sama mempunyai keunikan yang menggoda.

Dalam khazanah kesusastraan Inggris, Kazuo Ishiguro merupakan salah satu penulis produktif yang telah menguatkan kembali perspektif fiksi sastra kontemporer. Novelnya The Remains of the Day menjadi bestseller terbitan 1989 di Britania Raya yang menggiring Ishiguro memenangkan penghargaan Man Booker Prize 1989, sekaligus mengukuhkan pengakuan dan eksistensinya sebagai penulis sastra kontemporer dunia. Novel yang kaya detail penelitian kesejarahan ini adalah satu karya Ishiguro yang telah dialihbahasakan ke dalam bahasa Indonesia menjadi Puing-puing Kehidupan (2007).

The Remains of the Day juga sukses diadaptasi ke dalam film layar lebar 1993 dan berhasil mendapatkan penghargaan Academy Award pada tahun yang sama. Naskahnya diadaptasi oleh Ruth Prawer Jhabvala-seorang penulis sastra paskakolonial kelahiran Jerman yang hidup di Inggris dan kemudian lebih dikenal sebagai penulis naskah film. Film arahan James Ivory ini dibintangi oleh Anthony Hopkins sebagai Mr. Stevens dan Emma Thompson sebagai Miss Kenton. Mr.Stevens dan Miss Kenton ini adalah tokoh-tokoh yang merefleksikan elemen ironi tragedi dan komedi pada titik psikologi-sosial dalam sejarah kehidupan manusia terhadap nilai-nilai lingkungan-sosial antara kewajiban dan dedikasi, dengan setting di Inggris pada pertengahan tahun 1950-an. Pada masa itu, Ishiguro mampu memecahkan hegemoni efek peristiwa kolektif pada sebuah perubahan sejarah dalam konteks identitas kehidupan tokoh-tokoh itu, dan kemudian mentransformasinya dengan gagasan lokal sebagai tindakan individu.

Dalam sebuah wawancara yang dilansir situs writersblocpresents.com, Ishiguro menyatakan bahwa ia selalu tertarik pada apa yang terjadi di dalam diri setiap individu ketika mereka telah mengorbankan seluruh tenaga dan kehidupan mereka pada kelaziman nilai-nilai sosial, hanya untuk melihat mereka berubah. "Saat di akhir kehidupan, mereka menemukan bahwa dunia telah mengubah pemikiran tentang suatu nilai kebaikan dan keburukan. Namun ternyata bagi orang-orang ini, semuanya telah sangat terlambat" ujarnya.

Kazuo Ishiguro lahir pada 8 November 1954 di Nagasaki, Jepang. Ayahnya, Shizuo adalah seorang ahli kelautan, dan ibunya, Shizuko adalah ibu rumah tangga. Ishiguro hanya bisa menikmati kehidupan masa kecilnya selama enam tahun di Jepang, karena ia beserta kedua saudara perempuannya kemudian harus pindah dan tinggal di Inggris. Saat itu, ayahnya mendapat komisi dari pemerintah Inggris untuk melaksanakan projek kelautan. Meskipun saat itu keluarganya berharap hanya tinggal sementara di Inggris, namun pada kenyataanya pekerjaan sang ayah tidak mengizinkan mereka pulang kembali ke Jepang. Pada akhirnya mereka pun harus menjadi warga imigran tetap di Inggris.

Ishiguro dan kedua saudara perempuannya kemudian menjalani kehidupan masa kecil tipikal anak-anak Inggris pada umumnya. Namun, sang ayah sangat memegang kuat tradisi 
dan budaya Jepang sehingga saat berada di rumah, mereka diwajibkan berkomunikasi dengan bahasa Jepang dan menjalani kehidupan layaknya orang-orang Jepang. Keseharian keluarganya yang tetap mempertahankan tradisi dan budaya Jepang, telah menuntun Ishiguro memasuki dunia literer.

Bagi Ishiguro, menulis adalah ruang dan alat untuk mengawetkan kenangan tentang tanah kelahiran yang tidak dapat ia jumpai lagi hingga 1989. Dari situlah, lalu Ishiguro mengambil dan memperoleh gelar sarjana muda Ilmu Sastra di Fakultas Filsafat dan Kesusastraan di Kent University 1978. Selama menempuh pendidikan itu, Ishiguro bekerja sebagai pekerja sosial selama beberapa tahun sampai ia mampu mendapatkan penghasilan sebagai penulis. Selama masa waktunya sebagai pekerja sosial, ia bertemu dengan Lorna Anne MacDougall, yang kemudian menjadi istrinya pada 1986 dan seorang putri bernama Naomi yang lahir pada 1992. Ia pun berhasil merampungkan gelar Master of Arts dalam Program Penulisan Kreatif di Anglia East University di bawah bimbingan Malcolm Bradbury (1932-2000), seorang akademisi sastra dan novelis terkenal di Inggris.

Setelah memublikasikan beberapa judul cerita pendeknya seperti 'A Strange and Sometimes Sadness', 'Waiting for $\mathrm{J}^{\prime}$ ', dan 'Getting Poisoned' dalam antologi cerpen Introduction 7: Stories by New Writers (1981), dan beberapa artikel majalah pada awal tahun 1980-an, Ishiguro menerbitkan novel pertamanya $A$ Pale View of Hills (1982) yang berhasil memenangkan penghargaan Winifred Holtby Memorial Prize, penghargaan dari Perhimpunan Kesusastraan Kerajaan Inggris (Royal Society of Literature). Kemudian, novelnya yang berjudul An Artist of the Floating World (1986), tidak hanya memenangkan Whitbread Fiction Prize, tetapi juga dianugerahi sebagai Whitbread Book of the Year, Primio Scanno, dan masuk daftar nominasi penerima penghargaan Booker Prize. Tokoh-tokoh, setting, dan karakteristik kedua novel itu menggambarkan kondisi masyarakat Jepang (human condition) pasca-Perang Dunia II.

Dalam dunia literer, Ishiguro pun memiliki ketertarikan terhadap dunia musik dan film. Ishiguro menulis beberapa naskah film seperti $A$ Profile of Arthur J. Mason untuk stasiun televisi Inggris, Channel 4 (1984) dan The Gourmet untuk BBC, yang kemudian naskahnya dipublikasikan dalam Granta 43 (1987). Sedangkan ketertarikannya terhadap dunia musik, ia tuangkan dalam naskah film The Saddest Music in the World (2003), The White Countess (2005), dan antologi cerpen Nocturnes: Five Stories of Music and Nightfall (2009). Semua prestasi Ishiguro itu membuktikan, bahwa ketertarikannya pada tradisi menulis sejak kecil telah menjadi sebuah profesi yang sangat berharga dan menjanjikan baginya hingga saat ini.

Beberapa kritikus sastra di Inggris menilai karakteristik karya-karya Ishiguro berpatron spiritualisme para penulis Jepang, seperti Yasunari Kawabata, Kenzaburo Oe, dan bergaya New Age ala Haruki Murakami sehingga ia lebih pantas dikatakan penulis dari Jepang. Pernyataan itu didasarkan atas dua novel yang sebelumnya ditulis Ishiguro, yang banyak menceritakan kondisi manusia Jepang dan sebagian berlatar tempat di Jepang pascaperang. Namun, Ishiguro kemudian membantah keras pernyataan itu. Meskipun ia dilahirkan di Jepang, tetapi setelah dirinya menjadi warga negara Inggris dan sejak 1960 telah tinggal di London, ia telah menjadi bagian kultural masyarakat Inggris.

Bantahan Ishiguro itu kemudian dibuktikan dengan terbitnya The Unconsoled (1995), novel surealis penuh mimpi buruk tentang kehidupan seorang pianis di salah satu negara bagian Eropa Selatan. Karakteristik novel yang memenangkan penghargaan Cheltenham Prize ini, menyerupai karya-karya Franz Kafka yang penuh "keanehan dan mengganggu" itu, meskipun Ishiguro mengakui bahwa dirinya banyak terilhami oleh karya-karya Dostoevsky, 
Chekov, dan Tolstoy. Pada tahun itu pula, Ishiguro kemudian menerima OBE (Order of the British Empire) atas sumbangsihnya terhadap perkembangan kesusastraan Inggris. Ia pun menerima tanda kehormatan dari pemerintah Prancis dalam bidang seni, yaitu de l'Ordre des Arts et des Lettres (1998).

Kemudian, novel When We Were Orphans (2000) yang bercerita tentang tokoh sentral seorang detektif di London adalah salah satu entitas reaksi pembuktian Ishiguro terhadap para pembacanya yang mengarah pada pemahaman orientalisme. Tahun 2005, Ishiguro kembali mendapatkan penghargaan sebagai finalis Man Booker Prize atas novelnya Never Let Me Go. Novel yang membahas tentang kondisi manusia kloning dan pendonoran organorgan tubuh dari manusia kloning ini, ditulisnya sebagai sebuah kritik terhadap antroposentrisme, suatu gagasan etis atau layak diterima, dengan mengorbankan binatang non-manusia sebagai sebuah kebutuhan dan hasrat dalam kehidupan manusia itu sendiri.

Karya-karya Ishiguro telah diterjemahkan ke dalam 28 bahasa. Selama karier kepenulisannya, Ishiguro telah menulis berbagai masalah tentang autensitas, perbandingan, dan kecukupan pada setiap peristiwa dalam kehidupan manusia, serta resistensinya terhadap sebuah perubahan. Problematika perubahan sejarah dan kultur yang dialami Ishiguro bukanlah sebagai narasi transeden, melainkan sebagai sebuah kedalaman internal, struktur, dimensi teks, dan kombinasi dari keakraban perspektif seorang narator di bawah indera tindakan, dengan melibatkan transisi sejarah yang berkelanjutan.

Teks telah menjadi sebuah alat kritik dari suatu keunikan dan pertimbangan atas kegigihannya terhadap paradigma global, seperti hubungan, tradisi, etnis, dan skala. David Damrosch (2003) pernah membahas, tugas-tugas kesusastraan telah menyirkulasi melebihi keaslian kultur itu sendiri sehingga hampir seluruh karya-karya sastra lahir, yang kemudian kita kenal kini sebagai sastra nasional.***

*Terkadang menggunakan nama pena Fina Sato, penulis bergiat di ASAS dan MnemoniC.

Dimuat di surat kabar Pikiran Rakyat, 2009. 